УДК 801.73

\title{
Methodological Aspects of Study of the Modern Russian Literature Reception in China
}

\author{
Zhao Xue* \\ Harbin Polytechnic University \\ Harbin, China
}

Received 16.02.2015, received in revised form 20.04.2015, accepted 07.06.2015

The article substantiates the efficiency of selecting methodological principles for the study of modern Russian literature reception by Chinese readers. The author refers to the tradition of comparative literature, receptive aesthetics, analyses the concept that emerged within the framework of communication theory. The methodological «sieve» allows considering the reception of the texts produced in other cultures with regard to the factors (interference, stereotypes) that cause interpretation conflicts and communication failures.

Keywords: receptive aesthetics, interpretation, intercultural communication, comparative literature, imagology, Chinese reader.

DOI: 10.17516/1997-1370-2015-8-7-1494-1500

Research area: philology.

\section{Introduction}

The research, dedicated to the questions of reception of the texts produced in other cultures, has constituted a separate branch of literature studies. Aspects comprising the branch are determined by the selection of this or that methodological paradigm. Thus, application of the comparative literature methods provides the neutrality of study of the literary influence, while emphasis on the theoretic thesis of receptive aesthetics actualizes a different aspect of reception studies, i.e. the peculiarities of perception by a reader from a different culture. Selection of the appropriate methodological framework means more than substantiation of the planned research; it means a prospective analysis of possibilities provided by this or that method. The objective of the present article is to offer and to substantiate the productivity of the complex methodological paradigm for studying peculiarities of modern Russian literature reception by Chinese readers, including the phenomena of a stereotype, selfunderstanding, interpretation conflict etc.

\section{Methodological and theoretical orientations}

Obviously, the methodological foundation of the studies of literature reception in the intercultural dialogue process was laid by comparative literature studies encompassing the problems of mutual influence, attraction and repulsion, "import" of images, storylines,

(c) Siberian Federal University. All rights reserved

* Corresponding author E-mail address: zhaoxue1207@gmail.com 
and poetics (M. Guyard, P. van Tieghem, A.N. Veselovsky, V.M. Zhirmunsky, N.K. Gudziy, N.I. Konrad). This academic school of literature studies is not directly engaged with studying any problems of text reception by the readers, though it provides a series of postulates that seem to be relevant for the research of modern Russian literature perception by Chinese readers. First of all, there is a postulate of partial transformation of the perceived text due to the national development and national literary traditions. According to V.M. Zhirmunsky, it is the research of the reasons and the process of rethinking of the imported images itself that needs to become the main task for modern comparative literature (Zhirmunsky, 1979, 67). In his opinion, "no matter how diverse the development paths and tempos of different literatures are; they are vectored in the same direction from epoch to epoch, going through the same stages (Zhirmunsky, 1979, 137-138). It becomes especially relevant for Russian-Chinese literary relations of the $20^{\text {th }}$ century, when the development of China and Russia experienced the deep influence of Marxism-Leninism. The similarity of the social and political regime determined the closeness of the two countries in their literary tendencies, themes, genres, styles etc., which was inevitably reflected in the receptive mindset of the Chinese reader. Secondly, any comparative literature research today is unthinkable without another essential concept, which is the concept of dialogue by M. Bakhtin. According to Bakhtin, a dialogue is more than just openness for communication, the gift of a lively response to the opinions, judgments and ideas of other people; it is also an ability to provoke a response to one's utterances and actions. To our mind, this understanding of a bilateral dialogue is one of the epistemological basics for the research of Russian literature reception in China. In this context Russian literature is seen as a cultural phenomenon that possesses the potency of dialogue, infecting and provoking a response to itself; the term of "dialogue relations", therefore, includes more than literary texts, but also the opinions on literature and critic judgments of different genres.

"To The Methodology Of The Humanities" by $M$. Bakhtin words a relevant idea of the dialogueness of text and context. According to the researcher, the text lives only by coming into contact with another text (with context). "Only at this point of contact between texts does a light flash, illuminating both the posterior and anterior, joining a given text to a dialogue" (Bakhtin, 1986, 384). We may state that a text finds its new life in the context of a different culture, while within the reception by a foreign reader it is unwittingly perceived within the context of his "own", familiar literary texts. However, to our mind, it is necessary to account for the second, metatextual context, when the perceived literary text is exposed to the influence of the renditions/ interpretations existing in Russian studies in China.

There are some significant theoretical/ methodological principles for studying the reception of texts produced in other cultures, that appeared in the theory of communication, including philosophical, psychological, sociological, culturological, linguistic, semiotic concepts of intercultural dialogue. The concept of communication is understood in the socialsemiotic aspect, as a process of producing signs and their meanings, the perception of signs, understanding and producing of new meanings by the agents. R. Bart created a systematic model for the analysis of sign interaction with the cultural and personal experience of the recipient. In the opposition of "designation (denotation) and personal meaning (connotation)", the major subject of our study is the second member, as it is the one to reflect the interaction which occurs when a 
sign is coloured with the addressees' emotions and the values of their culture.

For the studies of Russian texts perception by Chinese readers in the process of intercultural communication it is necessary to understand the mechanism of the process based on the explanative model of communication. To our mind, the most efficient model for this purpose was suggested by W. Gudykunst and Y. Kim. This model brings the act of communication up to the individual level and demonstrates how cultural, sociocultural and psychocultural factors influence the process of communication. According to the authors, the environment of communication is not an isolated space or a closed system; it assumes different forms of exposure. Cultural, sociocultural, psychocultural and personal influences serve as conceptual filters, restricting the volume of information coming into the communicants' view. The psychocultural influences play the role of so-called cognitive and affective variables, and the sociocultural factors belong to the sphere of social organization of the communicative process (Gudykunst, Kim, 2002).

Methodological principles of receptive aesthetics allow us to focus on the mechanisms of reception and meaning-making. Let us remember the fact that a work of literature is "actualized" only at the moment of "encounter" with the reader, and this "actualization" directly depends on the recipient's "horizon of expectation", presenting the text as a dynamic system of potential meanings. After H. Jauss, we understand the horizon of expectation as the totality of social, culturalhistorical, psychological and other assumptions, determining, on one hand, the attitude of the author and, consequently, the text to the reader or the recipient, and, on the other hand, the attitude of the reader to the literary text.

Since the beginning of the $20^{\text {th }}$ century Russian Literature has been making a strong impact on Chinese society. According to Chinese philologist Lu Xun, "at the turn of the $19^{\text {th }}-20^{\text {th }}$ centuries Russian literature witnessed our young generation under the burden of oppression. Back then, we had realized that Russian literature was our guide and friend, because in it we found the kind spirit, suffering and struggles of the oppressed people" (Lu Xun, 1981, 459). From the beginning of the $20^{\text {th }}$ century until the 1950 -s, the majority of the Chinese had perceived Russian literature as a spiritual guide, a guide in social transformations. After a period of cooling in the relationships between the countries, after the political reforms and opening of China, Russian literature entered the everyday life of Chinese readers again. In our opinion, there was a certain momentum in the perception of Russian culture: pragmatism, assessment of the text from the point of view of usefulness and applicability.

The perception of a text produced in a different culture may suffer from absolute mismatch of the horizons. Such a situation is quite frequent among non-professional Chinese readers, who lack a cognitive base for perception of modern Russian literature. It explains the abruption of some texts or negative criticism. The data provided by scientific and literary critic researches illustrates a different situation of interaction between the horizons, when a text finds a specific novelty against the background of the aesthetic principles familiar to the reader. Such reading aids coping with the inertance of the readers' perception and the stereotypeness of their consciousness, expands the reader's horizon of expectation. Such variant of interpretation it its textual wording demonstrates the traces of partial match and mismatch of the horizons. For a Chinese reader, a modern Russian text is full of "communicative uncertainty" (R. Ingarden). The mechanism of clarification of these uncertainties explains the psychological targets of communication theory and categorization concept (process of systematization and 
arrangement of information in a convenient form by classifying it into groups, classes, types, i.e. categories). Categorization "simplifies" reality, making it easier to understand and to study (Sadokhin, 2004, 185), being a necessary factor of the perception of other literatures (or, in a wider sense, of other cultures). Thus, as soon as a professional Chinese reader has developed a category of "Russian literary tradition", it is often "applied" to modern Russian texts, determining the way of interpretation. However, at the first encounter with a Russian literary text, a nonprofessional reader perceives them, relying on the categories formed by their previous life experience, personal interests, background, socioeconomic factors etc. In the second case the possibility of misunderstanding, non-adequate interpretation or negative evaluation is higher. The category of "Russian literature tradition" may act as a stereotype. The concept of a stereotype (W. Lippmann) means knowledge that is not derived from the person's own experience and plays a role of a clue that helps the person to develops his own assumptions, suggestions and appraisals. The majority of Chinese readers know Russian culture and literature through mass media, radio, internet and television (from the main sources of stereotypes). Russian literature is often severely criticized in Chinese literature magazines and newspapers. It is believed to be going through a crisis, losing its status of a guide in moral values, decreasing in quality and being inferior to classic literature. Such judgments and evaluations form the pre-knowledge of a Chinese reader, their "horizon of expectation" and their stereotypes, preventing, therefore, the establishment of interest to Russian literature in China.

The majority of Chinese readers do not have profound knowledge of Russian literature (especially modern literature) or big experience of reading Russian texts. At the encounter with
Russian literature they usually demonstrate their natural inclination to perceiving it, first of all, from the view of Chinese culture and tradition, and secondly, through the prism of the stereotypes of Russia and Russian literature existing in the Chinese readers' mind. The literary critic judgments available in the Internet help reconstructing these stereotypes.

The process of Russian literature perception in China is also a process with inevitable misunderstandings and misinterpretations. For this reason, communication theory is engaged with the study of the phenomenon of "noise", thinking stereotypes. By noise we understand the factors that reduce the quality of communication, such as asymmetry, stereotypic reactions, linguistic mistakes etc. (Leontovich, 2003, 273). Noise leads to communication failures, i.e. to the obstruction of the communicative chain or distortion of information. The latter is often resulted from interference, i.e. invasion of the native cultural factors into the interpretation of information produced in another culture (Leontovich, 2003, 275). Readers prefer the information and the meanings that resonate with their internal logics, confirm their opinion and conform to their values and priorities. In its most radical manifestation, stereotypical interpretation is made exclusively from the point of view of the recipient's native culture. There is no stereotype-free recipient; stereotypes form a part of cultural thinking, and Chinese readers are not an exception. Texts by Chinese scientists and literary critics allow us to reconstruct a series of stereotypes associated with Russia. Based on her sociopsychologic research, N. Bokova made a relevant conclusion on some stereotypes of Russia in the consciousness of Chinese people: Russia is a country of great history, literature, music, and architecture; the image of the USSR is more attractive than that of modern Russia; the most outstanding Russian political leaders 
are V.I. Lenin (64.9\%), J.V. Stalin (40.5\%), and V.V. Putin (81.6 \%); Putin is a respected, strong and honoured leader; Gorbachev period is a mistake of Russia; active intercultural exchange of Russia resulted in the distortion of historical achievements which, in its turn, leaded to shortfall policies; Russia is not safe for visitors etc. (see more: Bokova, 2010).

Thereisanewbranchofcomparativeliterature that has been recently outlined by A. Lortolari, $\mathrm{Ch}$. Corbet, M. Cadeau, H. Dyserinck: imagology, a discipline studying the images of "other", "alien" nations, countries, cultures that are foreign for the recipient. The basic concept opposition of imagology is "insiders vs. outsiders" defined by Iu.S. Stepanov as an "opposition which pervades the culture and acts as a basic concept of any outlook, let it be collective, massive, folk, national, and, of course, Russian as well" (Stepanov, 1997, 472). The emergence of imagology is the sign of transition from essentialism to constructivism concerning the understanding of national identity and mentality issues. Here we accept the suggestion that the concepts of "insiders" and "outsiders" are dynamically constructed by the community. At the same time, it is evident that such constructions find their reflections both in literary text and in receptive texts. Something Russian as an outsider for a Chinese recipient is both the image of Russian people, Russian culture, and the values it encompasses. At various stages of Russian-Chinese relationships, the principles of constructing the image of Russia as an image of an outsider have changed. According to Li Yonghong, Russian means other-minded; Russian literature contains an intensive religious aspect of meaning that cannot be rationally cognized. At the same time, the principle typical of Chinese culture is the "golden mean" principle originated from the restriction and oppression of feelings and emotions (Li Yonghong, 2009, 57-58). The difference of cultures and types of thinking, as well as that of world interpretation, becomes evident in the situation of perception of a text produced in a different culture. The process of understanding of such a text is always the process of self-understanding (Govorukhina, 2009, Govorukhina, 2010). Developing this idea, R. Weaver came up with the iceberg theory. Culture can be metaphorically compared to an iceberg, a small part of which is seen above the water, while its greater part is hidden underneath. The visible part is formal culture. At this level, intercultural problems hardly ever happen; this is the level of behaviour model teaching. The invisible part is the informal level, where all acts and behaviour are automatic, subconscious. The person becomes aware of them only in extraordinary, extreme or non-common situations at the encounters with people from other cultures. According to R. Weaver, at the collision of two cultural icebergs the previously unconscious part of cultural perception comes up on the conscious level, bringing the person to treating both his own and the alien culture with greater care and attention (Weaver, 1996, 159-160). The iceberg theory explains the presence of self-reflection in the meta-literary texts produced by Chinese professional readers. At the encounter with Russian alien culture the difference between the cultures becomes clearer, with Chinese cultural uniqueness coming to the fore. To our mind, it is the moment of realization and development of national identity that is later expressed in the reflective texts.

\section{Conclusion}

The selected theoretical and methodological principles make up a methodological base which may be used for the research of modern Russian literature perception by Chinese readers, considering that:

- the perceived text is a dynamic system of meaning potencies borne in a dialogue; 
- the process of reception includes partial transformation of the perceived texts which brings up the prospective of studying the image of Russian literature within the "horizon of expectation" of the Chinese reader, the cultural mindsets that determine the interpretation and evaluation of a Russia literary text;

- for a recipient, texts produced in a different culture are full of "communicative uncertainty", the clarification of which determines the success or failure of general interpretation. The explanation of the interpretation conflict requires research of sociocultural, psychocultural factors, different types of "noise" and thinking stereotypes;

- perceived by the reader, the text produced in a different culture is consciously and subconsciously embedded into/compared with the context of the "insider" works of literature and metatextual context (the totality of renditions/interpretations existing in Russian studies in China;

- the process of understanding a text is also a process of self-understanding. Accepting this postulate, we can also study the literary critic and scientific reflections of Chinese readers in the aspect of national self-identification.

\section{References}

1. Gudykunst, W.B., Kim, Y.Y. Communicating With Strangers: An Approach To Intercultural Communication. New York: McGraw-Hill, 2002.

2. 鲁迅. 鲁迅全集. 北京大学出版社:北京 Lu Xun, Complete Works. Beijing: Beijing University Publishing House, 1981.

3. 刘永红. 中俄文学的文化内涵分析// 中国俄语教学. Li Yonghong. An Analysis Of The Cultural Content In Russian And Chinese Literature. The Teaching Of Russian Language In China), 2009.

4. Weaver, R.L. Understanding Interpersonal Communication. Harper Collins College Publishers, 1996.

5. Bakhtin, M.M. Estetika slovesnogo tvorchestva [Aesthetics Of Verbal Creation]. Moscow: Iskusstvo, 1986.

6. Bokova N.B. Simvolicheskiy obraz Rossii v massovom soznanii Kitaia [Symbolical Image Of Russia In The Mass Consciousness Of China] // Aktual'nye problemy sovremennoy politicheskoj psikhologii. Edited by E.B. Shestopal, p. 159-169. Moscow, 2010.

7. Govorukhina Iu.A. Struktura literaturno-kriticheskoy deiatel'nosti [Structure Of Literary Critic Activity] // Kritika i semiotika. No.13, p. 193-203. 2009.

8. Govorukhina Iu.A. Poznavatel'naia identichnost' sovremennoy literaturnoy kritiki [Cognitive Identity Of Modern Literary Criticism] // Sibirskiy filologicheskiy zhurnal. No.1, p. 7688. 2010.

9. Zhirmunsky V.M. Sravnitel'noe literaturovedenie [Comparative Literature] // Vostok i Zapad: izbrannie trudy. Leningrad: Nauka, 1979.

10. Leontovich O.A. Rossia i SSHA. Vvedeniye v mezhkul'turnuiu kommunikatsiiu [Russia And The USA. Introduction To Intercultural Communication] Volgograd: Peremena, 2003.

11. Sadokhin A.P. Mezhkul'turnaya kommunikatsiia [Intercultural Communication] Moscow: Alfa-M; INFRA-M, 2004. 
12. Stepanov Iu.S. Konstanty. Slovar' russkoy kul'tury. [Constants. Dictionary Of Russia Culture] Moscow: Shkola russkoy kultury, 1997.

\title{
Методологические аспекты
}

\section{изучения рецепции современной русской литературы в Китае}

\author{
Чжао Сюе \\ Харбинский политехнический университет \\ Харбин, Китай
}

В статье обосновывается продуктивность выбора ряда методологических положений для изучения рецепции современной русской литературы китайским читателем. Автор обращуается к традиции сравнительного литературоведения, рецептивной школь, анализирует концепции, возникиие в рамках теории коммуникации. Полученная методологическая сетка позволяет рассмотреть рецепцию инокультурного текста с учетом факторов (помехи, стереотипь), порождающих конфликты интерпретаций, сбои коммуникации.

Ключевые слова: рецептивная эстетика, интерпретация, межкультурная коммуникация, сравнительное литературоведение, имагология, китайский читатель.

Научная специальность: 10.00.00 - филологические науки. 